\title{
Russian Studies
}

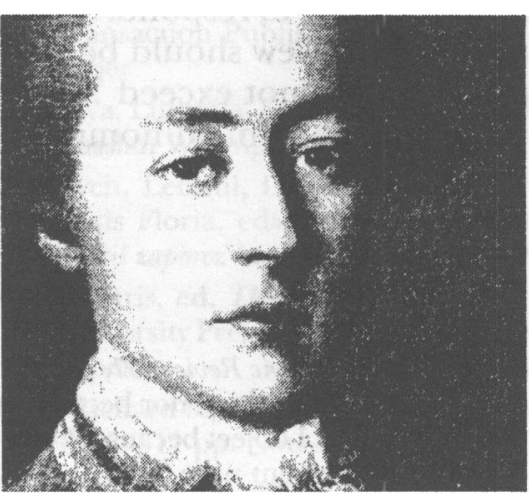

Working the Rough Stone

Freemasonry and Society in Eighteenth-Century Russia

Douglas Smith

"The best work on Russian Freemasonry.... Interesting and convincing." - Gary Marker, SUNY Stony Brook

The first scholarly history of Russian Freemasonry to appear in English, Working the Rough Stone explains how the Masonic lodges helped to prepare the way for the birth of civil society in Russia. Home to the country's educated classes, the lodges offered a social alternative to the world of the tsarist court and the opportunity for intellectual and moral enlightenment.

Based on extensive archival research, Working the Rough Stone compels us to rethink long-held assumptions about Russian society and expands our understanding of the complex processes of Westernization and identity formation. 246 pages $\$ 38.00$ cloth

\section{Autocracy under Siege}

Security Police and Opposition in Russia, 1866-1905

Jonathan W. Daly

"A clear and readily comprehensible guide to the complex and changing institutions of the tsarist security police." -Dominic Lieven, LSE

Examining the role of the security police in the struggle between the Imperial regime and those dedicated to its destruction, Autocracy under Siege shows how the steady growth of antigovernmental activity compelled Russia's leaders to expand, to improve, and to refine their antirevolutionary institutions and weapons.

Drawing upon a wealth of sources, including many recently declassified archival documents, this probing analysis of the interplay between regime and opposition illuminates larger issues concerning the Imperial regime and its efforts to modernize during the years before the Revolution of 1905.

272 pages $\$ 38.00$ cloth

\section{ताT}

\section{Northern Illinois}

University Press

DeKalb 60115 815.753.1075

www.niu.edu/univ_press 


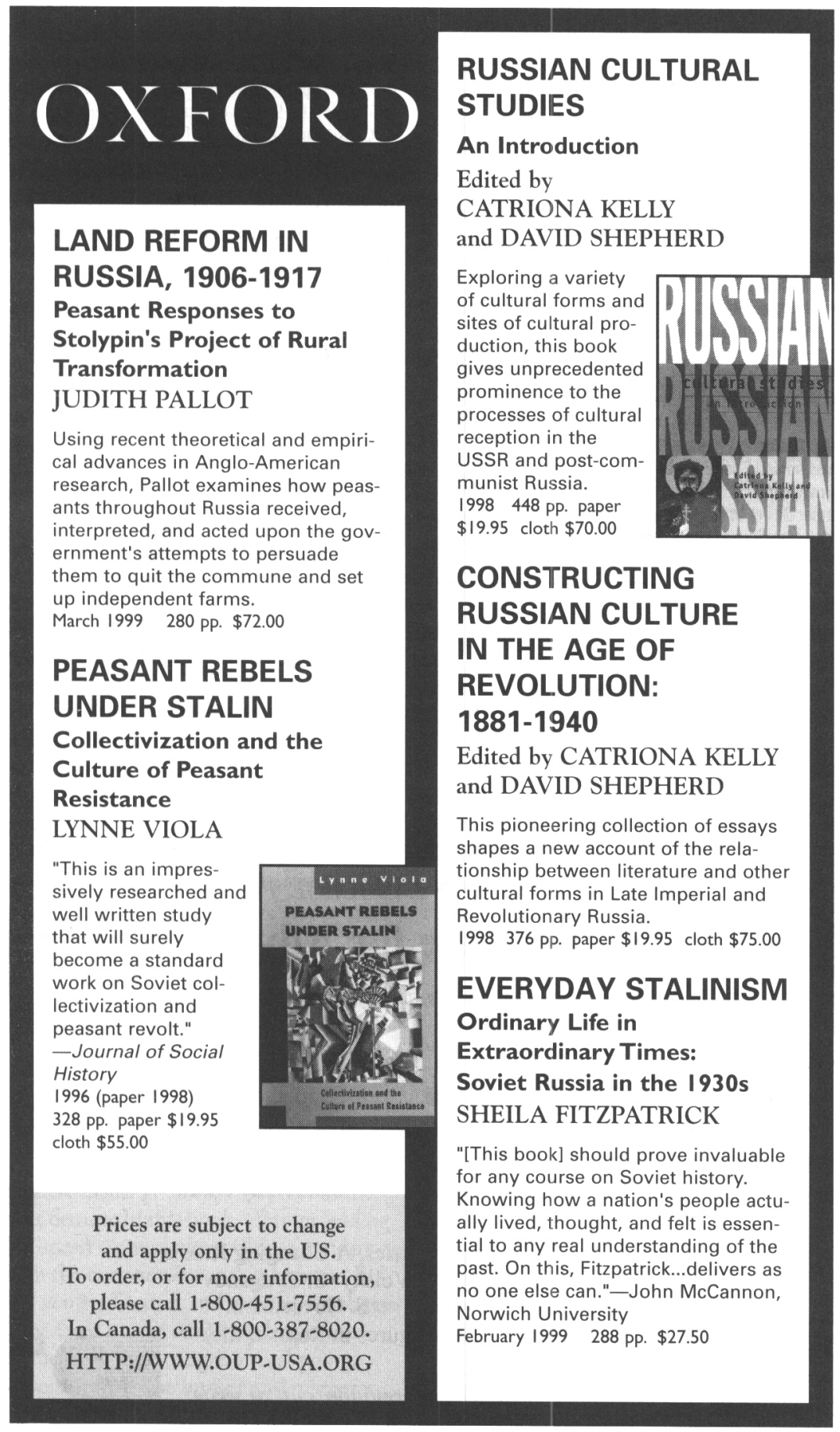




\begin{tabular}{|c|c|}
\hline $\begin{array}{l}\text { The Industrialisation of } \\
\text { Soviet Russia (6 volumes) } \\
\text { R.W. Davies } \\
\text { "Davies is the foremost economic } \\
\text { historian of Stalin's Soviet Union" } \\
\text { - Ronald Suny, Business History Review } \\
\text { "a genuine chronicle of the } \\
\text { industrialization of Soviet Russia" } \\
\text { - A. Solokov and L.Vonyushkina, } \\
\text { Obshchestvennaya mysl' za rubezhom, Moscow } \\
\text { Planned as a number of independent volumes, } \\
\text { this major work will cover the years 1929-1937, } \\
\text { the crucial period of the first two five-year plans. } \\
\text { In these years the Soviet Union became a great } \\
\text { industrial power, and the economic system took } \\
\text { the form which, in its main features, it retained } \\
\text { until the collapse of the Soviet Union in 1991. } \\
\text { R.W. Davies is Emeritus Professor in the Centre for } \\
\text { Russian and East European Studies at the University of } \\
\text { Birmingham, UK. He is an historian and specialist on the } \\
\text { former Soviet Union, who has published many books and } \\
\text { articles on Soviet history between the wars, and on } \\
\text { contemporary current affairs. }\end{array}$ & 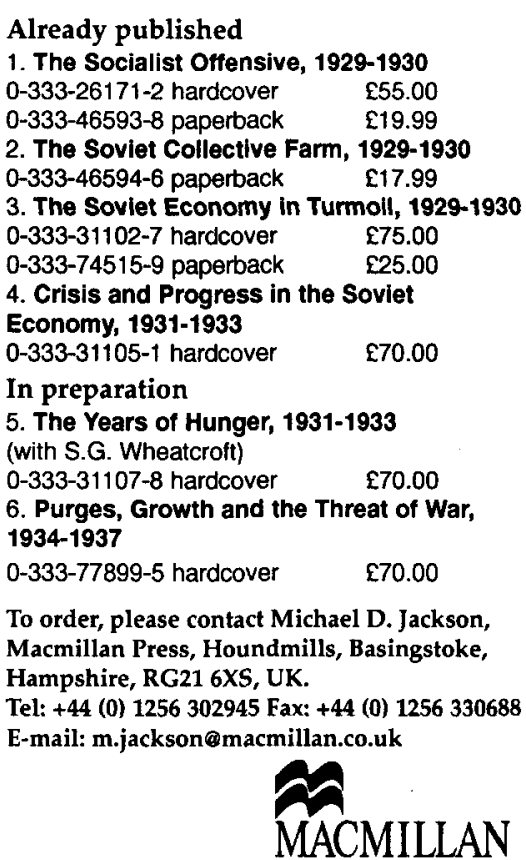 \\
\hline
\end{tabular}

A COMPREHENSIVE PROGRAM IN LANGUAGE, POLITICS AND CULTURE

\title{
The Moscow Institute for Advanced Studies
}

\author{
in association with the International University of Moscow
}

- Year, semester, and summer programs

-Beginning, intermediate, and advanced levels of instruction

-Vast course selection

-Courses in English and Russian
-Internships

- Grad and faculty Research program -Location in the center of Moscow - Financial aid available

-University credit

And our exclusive lecture series, A Changing Russia featuring lectures by: A. Volsky ${ }^{\star G}$. Zyuganov -I. Melnikov`I. Antonova`S. Govorukhin` ...and other prominent figures in Russian life.

For complete program information, call or write: Moscow Institute for Advanced Studies 152 West 57th St., 48th Floor, New York, NY 10019

Tel: (212) 245-0461 Fax: (212) 489-4829 www.studyabroad.com/moscow e-mail: mifasl@aol.com 


\section{NEW FROM CAMBRIDGE}

\section{Nation-building in the} Post-Soviet Borderlands

The Politics of National Identities

Graham Smith, Vivien Law,

Andrew Wilson, Annette Bohr

and Edward Allworth

The emergence in 1991 of the fourteen borderland post-Soviet states has been accompanied by the reforging of their national identities. This book analyzes these national identities and explores their consequences for the borderland states, with substantive studies drawn from the Baltic states, Ukraine and Belarus, Transcaucasia and Central Asia.

0-521-59045-0 Hardback \$59.95

0-521-59968-7 Paperback \$22.95

\section{Freedom and Terror in the Donbas}

A Ukrainian-Russian Borderland, 1870s-1990s

Hiroaki Kuromiya

A little-known former Cossack land, the Donbas remained a haven for fugitives, providing freedom to whoever needed it. As a result, Stalin's Terror was extraordinarily harsh in the Donbas. This book paints a detailed yet panoramic picture of the tumultuous history of the Donbas and analyzes critical events in modern Ukrainian and Russian history from a regional perspective.

\section{Cambridge Russian, Soviet}

and Post-Soviet Studies 104

0-521-62238-7 Hardback \$44.95

\section{Recreating Europe}

The European Union's Policy towards Central and Eastern Europe

Alan Mayhew

The enlargement of the European Union to include central and eastern Europe is the greatest challenge Europe will face in the next decade. In this book a former leading European Commission official considers both the current relationship between EU and central Europe, and the main problems to be faced on the road to enlargement, including reform of agricultural policy, regional policy, the budget and migration. 0-521-63086-X Hardback \$59.95 0-521-63897-6 Paperback \$22.95
Standard English-SerboCroatian, SerboCroatianEnglish Dictionary

A Dictionary of Bosnian, Croatian, and Serbian standards

Morton Benson

"It is a pleasure to express the judgment that this work is a model of lexicographic excellence."

- Library Journal

0-521-64209-4 Hardback $\$ 85.00$ 0-521-64553-0 Paperback \$39.95

\section{The Cambridge Companion} to Modern Russian Culture Nicholas Rzhevsky, Editor

These newly commissioned essays explore Russian culture in all its rich diversity, including the historical conditions that helped shape it and the arts that express its highest achievements.

Contributors: Nicholas Rzhevsky, Dean Worth, Dmitry S. Likhachev, Mark Bassin, Pierre Hart, Abbott Gleason, Catriona Kelly, David Bethea, John Bowlt, Harlow Robinson, Laurence Senelick, Nikita Lary

Cambridge Companions to Culture

0-521-47218-0 Hardback \$54.95 0-521-47799-9 Paperback \$19.95

\section{A History of the} Soviet Union from the Beginning to the End Peter Kenez

Peter Kenez traces the development of the Soviet Union from the Revolution, through the 1920s, the years of the New Economic Policies and into the Stalinist order. He shows how post-Stalin Soviet leaders struggled to find ways to rule the country without using Stalin's methods but also without openly repudiating the past, and to negotiate a peaceful but antipathetic coexistence with the capitalist West. $\begin{array}{lll}0-521-32426-2 & \text { Hardback } & \$ 49.95 \\ 0-521-31198-5 & \text { Paperback } & \$ 17.95\end{array}$

Available in bookstores or from

\section{CAMBRIDGE UNIVERSITY PRESS}

40 West 20th Street, N.Y., NY 10011-4211

Call toll-free 800-872-7423

MasterCard/VISA accepted.

Prices subject to change.

Web site: http://www.cup.org 


\section{Tolstoy ON THE COUCH Misogyny, Masochism and the Absent Mother DANIEL RANCOUR-LAFERRIERE}

In 1888 , Leo Tolstoy mysteriously declared that sexual intercourse should no longer exist. Years later he would admit to being "horrified" by this pronouncement, but still remained an ardent believer in sexual abstinence. Frequenter of brothels in his youth, father of thirteen children by his wife and at least two children by peasant women before he was married, Tolstoy now had the audacity to suggest that people should stop having sex. How can such a repudiation be explained?

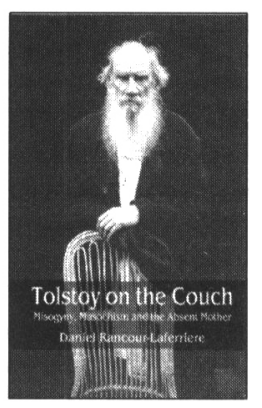

Beginning with Tolstoy's Kreutzer Sonata-his first written "declaration of war on human sexuality"-Tolstoy on the Couch takes us on a sweeping psychoanalytic tour of Tolstoy's diaries and other private materials, revealing behind his campaign for celibacy a painful and complicated drama of early childhood. Rooting Tolstoy's polarized feelings about women and sexuality in his uncontrollable rage toward the mother who died when he was an infant, RancourLaferriere offers profound psychbiographic insights into Tolstoy's lifelong animosity toward women-and into the women he loved to hate.

0-8147-7509-8 / \$40.00 CLOTH

\section{NYU PRESS}

\section{1-800-996-NYUP www.nyupress.nyu.edu}

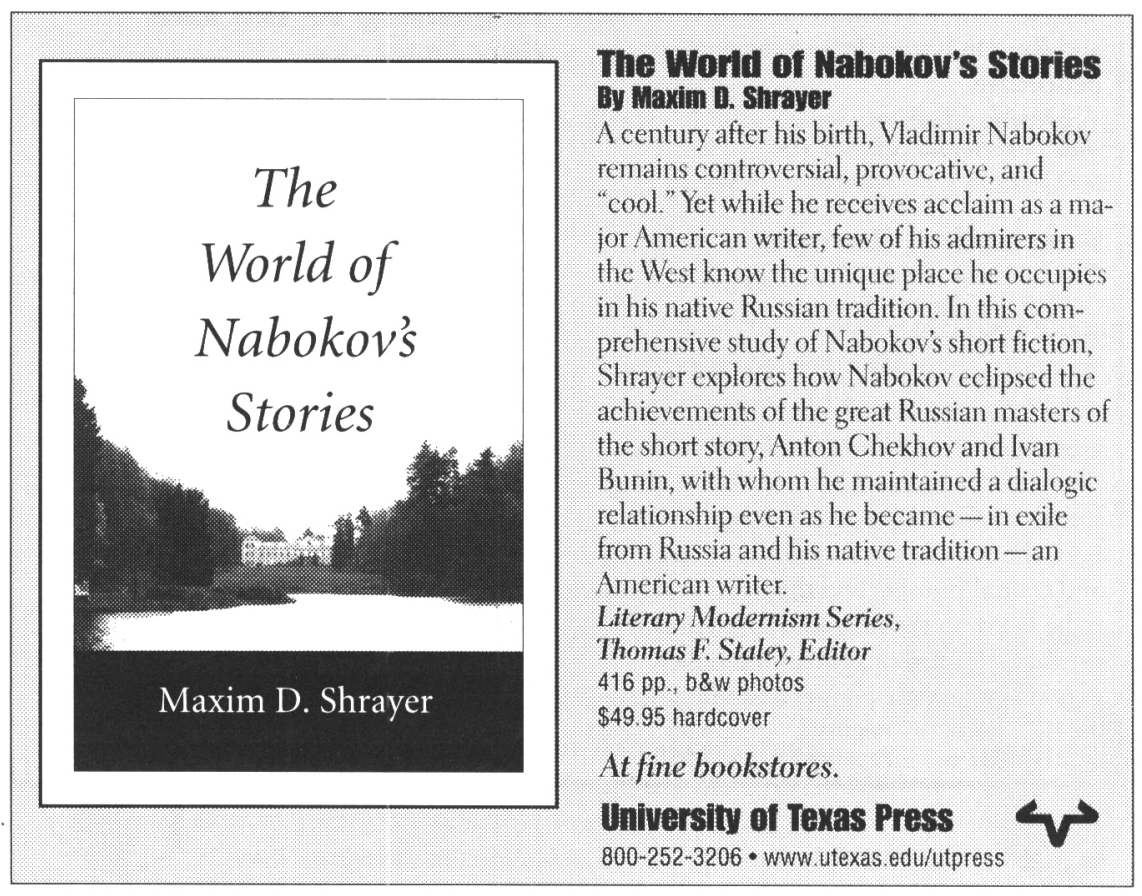




\section{Rowman $\mathfrak{d}$ Littlefield}

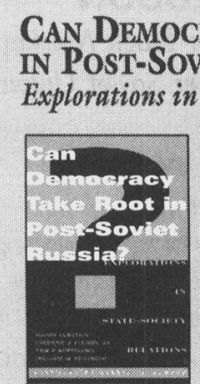

contemporary

- Robert C. Tucker, Princetonia."

University

"It is not often that social science theories stand up so well thirty years on in circumstances unimaginable at their birth. The power of congruence theory is remarkable." - Robert Putnam, Harvard University $\$ 22.95$ paper $\cdot \$ 69.00$ doth

\section{Dilemmas of Transition}

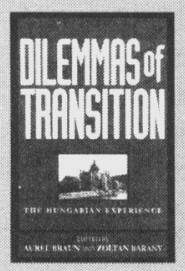

Edited by Aurel Braun AND ZolTaN BaRaNY

"insightful and wellbalanced.... an indispensable handbook." - János Kornai, Harvard University and Collegium Budapest

\section{REQUIEM FOR AN ARMY}

The Demise of the East German Military

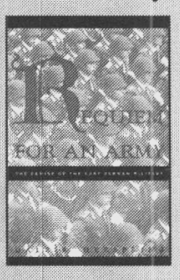

By Dale R. Hrrspring

"Dale Herspring has uncovered a fascinating story about the conduct and collapse of the East German army during both the protest against the East German government and also the reunification of Germany."

- Ronald A. Francisco, University of Kansas

$\$ 24.95$ paper $-\$ 64.00$ cloth

\section{The Russian Question}

Nationalism, Modernization, and

\section{Post-Communist Russia}

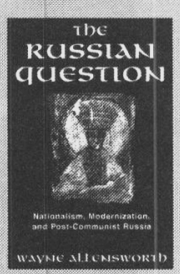

By WaYNe

ALLENSWORTH

This timely book draws on rare Russian sources to explore the ways nationalists have responded to modernization and to chart a likely course for

Russia's future development.

$\$ 23.95$ paper $\cdot \$ 69.00$ doth
JUSTICE AND SOCIAL RECONSTRUCTION IN BOSNIA-HERZEGOVINA IN GLOBAL

Perspective

EDITED BY ThOMAs

CUSHMAN

Explores the little-studied process of social justice and reconstruction in Bosnia-Herzegovina in the global context. $\$ 22.95$ paper $-\$ 65.00$ cloth

\section{Philosophical REFLECTIONS ON THE Changes in Eastern EUROPE}

By William L. McBride Two philosophers-one American, one Bulgarianoffer alternative perspectives on the commonalities and differences among countries in central and eastern Europe. $\$ 16.95$ paper $\bullet \$ 57.95$ cloth
Many Shades of Red State Policy and Collective Agriculture

Edited by Mieke Meurs

Draws on newly available resources to illuminate the costs, benefits, successes, and failures of cooperative agriculture. $\$ 21.95$ paper $\bullet \$ 62.00$ cloth

4720 Boston Way $\cdot$ Lanham, MD 20706 www.rowmanlittlefield.com

1-800-462-6420

An Independent Publisher for the 21st Century 
NEW FROM ST. MARTIN'S PRES S

\section{COLLISION AND COLLUSION}

The Strange Case of Western Aid to Eastern Europe 1989-1998 Janine R.Wedel

"Wedel's bold, invaluable report is frightening for its revelations and political implications, both in the US and ex-Eastern bloc." $1998 \cdot 304 \mathrm{pp}$. _Publishers Weekly

$0-312-21215-\mid \$ 27.95 \mathrm{cl}$.

\section{THE TRANSITION} FROM COMMUNISM TO CAPITALISM

Ruling Elites from

Gorbachev to Yeltsin

David Lane

and Cameron Ross

Explores the structure of classes and elites in the transformation of Russia, and offers new ways of examining Russian politics. $1998 \cdot 272$ pp. $0-3|2-2| 6 \mid 2-2 \$ 55.00 \mathrm{cl}$.

\section{THE SENSE OF FORM} IN LITERATURE AND LANGUAGE

Michael Shapiro

Demonstrates how form in language determines the meaning of texts by Dostoyevsky, Bulgakov,

Pushkin, and others.

$1998 \cdot 224$ pp.

$0-312-21383-2 \$ 45.00 \mathrm{cl}$.

Semaphores and Signs
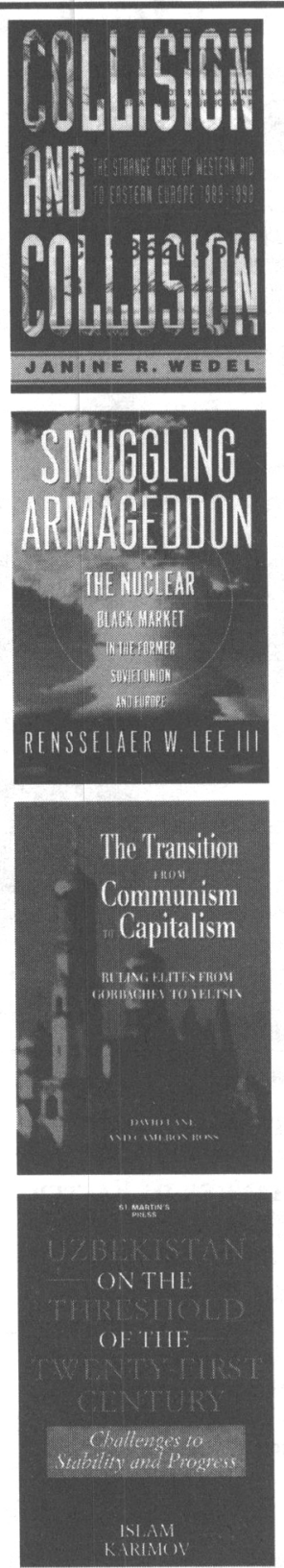

\section{SMUGGLING}

\section{ARMAGEDDON}

The Nuclear Black Market in the Former Soviet Union and Europe

Rensselaer W. Lee III "A good overview, giving some history of the smuggling of nuclear materials... highly recommended."

$$
\text { - Library Journal }
$$

$1998 \cdot 220 \mathrm{pp}$

$0-3|2-2| 156-2 \$ 26.95 \mathrm{cl}$.

\section{UZBEKISTAN ON \\ THETHRESHOLD OF THE TWENTY-FIRST CENTURY}

Challenges to Stability

and Progress

Islam Karimov

The author, President of Uzbekistan, explores the challenges faced by the country in the twenty-first century. $1998 \cdot 224 \mathrm{pp}$. $0-3|2-2| 368-9 \$ 39.95 \mathrm{cl}$.

\section{EASTERN EUROPE SINCE 1945}

Second Edition

Geoffrey Swain and Nigel Swain

Sets the historical context in which Eastern Europe is dividing between areas where democracy and pluralism appear firmly established, and those where they do not. $1999 \cdot 288 \mathrm{pp}$. $0-312-21690-4 \$ 21.95 \mathrm{pb}$.
ST. MARTin's PRESS Scholarly \& Reference Division
175 Fifth Avenue

NEW York, NY 10010

1-800-221-7945

$1-80 U-\angle 21-1943$ 


\section{Forthcoming in Slavic Review}

\section{Special Pushkin Issue}

Introduction by guest editor, Stephanie K. Sandler

Alexander Dolinin, Historicism or Providentialism?

Pushkin's History of Pugachev in the Context

of French Romantic Historiography

Sergei Davydov, The Ace in the "Queen of Spades"

David Shengold, Adding to the "Guest" List:

Hugo's Hernani and Pushkin's Don Juan

Catharine Theimer Nepomnyashchy, Pushkin's The Bronze Horseman

and Irving's "The Legend of Sleepy Hollow":

A Curious Case of Cultural Cross-Fertilization?

James L. Morgan IV, Love, Friendship, and Poetic Voice in Aleksandr Pushkin's Lycée Elegies

Ian M. Helfant, Pushkin's Ironic Performances as a Gambler

Leslie O'Bell, Writing the Story of Pushkin's Death

Wendy Slater, The Patriots' Pushkin 